\title{
ARTICLE
}

\section{Payment types included on technology licensing agreements and earnings distribution among Portuguese universities}

\author{
A. Rocha ${ }^{a, b, *}$, R. Lima ${ }^{a, c}$, M. Amorim ${ }^{d}$, F. Romero ${ }^{a}$ \\ a Department of Production and Systems, University of Minho, Braga, Portugal \\ ${ }^{\mathrm{b}}$ Management School of the Polytechnic Institute of Cávado and Ave, Barcelos, Portugal \\ ${ }^{\mathrm{c}}$ ALGORITMI Research Centre, Production and Systems Engineering, University of Minho, Guimarães, Portugal \\ ${ }^{\mathrm{d}}$ Department of Economy, Management and Industrial Engineering, University of Aveiro, Aveiro, Portugal
}

Received 4 June 2017; accepted 6 November 2017

Available online 24 November 2017

\author{
JEL \\ CLASSIFICATION \\ O310; \\ 0320; \\ 0340

\section{KEYWORDS} \\ Technology transfer; \\ Technology \\ evaluation and \\ licensing; \\ University and \\ industry relation; \\ Payment types; \\ Earnings distribution
}

\begin{abstract}
Knowledge and technology transfer practices between universities and industry are aimed to enhance the value of research and development outcomes. They allow researchers and universities to obtain resources and revenues through the establishment of licensing and cooperative research and development agreements. The main objective and contribution of this paper is to provide evidence on what are the main payment types in use by university Technology Transfer Units (TTUs) ensuring a comprehensive overview of the concepts and practices under assessment. This approach also gave us the opportunity to know the earnings distribution among the Portuguese public universities, and to list different dispositions influencing the value of a licensing agreement. Interviews to eight Portuguese university TTUs have been done as a way of perceiving from an insider perspective the issues that this paper wants to emphasize and an extensive literature review has been done, which included the review of the intellectual property regulation of most Portuguese public universities.

(c) 2017 Instituto Politécnico do Cávado e do Ave (IPCA). Published by Elsevier España, S.L.U. All rights reserved.
\end{abstract}

\footnotetext{
* Corresponding author.

E-mail address: arocha@ipca.pt (A. Rocha).
} 


\section{Introduction}

Research and development (R\&D) is the predecessor of new knowledge, patents and technology that might be converted into innovations, enhanced products or explicit or tacit knowledge. To leverage the value of R\&D outcome evaluation practices and methods may be used to combine the unique features of an invention or technology with the needs and interests of different organizations. Foreseeing this end, universities have adopted knowledge valorization strategies to foster the practical application of research and development results. In this context, technology evaluation and licensing activities allow research staff and universities to achieve revenues by means of the establishment of technology transfer agreements. In order to better understand this process and to improve the access to information on specific practices to support the commercialization of inventive activities this paper aims to provide evidence on what are the main payment types in use by university Technology Transfer Units (TTUs), and also to provide knowledge regarding the earnings distribution among the Portuguese universities, and to list different dispositions influencing the value of a licensing agreement. We noticed that the literature review on these issues is rather fragmented, in the sense that they usually isolate a limited number of factors to treat them as independent variables (Wright, 2014). It is this gap that the present paper intends to address by clearly stating the payment types in use by the Portuguese TTUs and by stating the earning distribution among Portuguese universities.

\section{Methodology}

The study involved an extensive literature review and the collection of complementary information by enquiring the heads of staff of eight university TTUs of Portuguese universities, employing a semi-structured survey. The data has been collected between October 2016 and February 2017.

The eight TTUs addressed were bond to eight Portuguese universities and they all have answered the semi-structured survey, namely:

1. University of Minho - TecMinho

2. University of Porto: UPIN

3. University of Aveiro: UATEC

4. University of Coimbra: DITS

5. University of Beira Interior: Innovation and development office

6. University Nova of Lisboa: RIA - Research and Innovation Accelerator

7. University of Évora: Technology transfer office

8. University of Algarve: CRIA

This sample was purposefully chosen due to the high regional and national influence of the universities, and due to the experience and ability of the TTUs to provide data that expand the understanding of technology transfer processes. Six out of the eight universities appear regularly in world rankings of the top 1000 universities (CWUR, 2015).

The semi-structured survey was divided in two parts, one focused on technology evaluation methods and practices, and the other one focused on licensing agreement payments. On both parts we used a Likert scale to classify the frequency of use of each issue under analysis. The higher the value, the higher were the frequency of use, in a scale between 1 and 5 .

The approach was exploratory and descriptive, but also analytical in the sense that it states the issues at stake on the establishment of a payment structure on technology transfer agreements, and a statistical analysis has been done using the One-sample $T$-tests for the means of relevant variables. IBM SPSS Statistics 19 has been used to perform this analysis.

As a framework for the One-sample $T$-test analysis we have used throughout the article two hypotheses, considering a 95\% confidence interval:

HO. The average frequency is equal to 3 , the payment is frequently included on technology transfer agreements by the TTUs who participated in this study.

H1. The average frequency is not equal to 3 , the payment is not frequently included on technology transfer agreements by the TTUs who participated in this study.

This approach allowed us to identify the types of payment used by the TTUs in licensing agreements.

The intellectual property rights regulation of all the public Portuguese universities, with the exception of the University of Azores and University of Madeira, have also been reviewed to identify the earnings distribution arising from licensing agreements.

\section{Payment types}

When defining the payment structure we must consider different dispositions which might influence the licensing agreement value. Some of those dispositions are:

- At a technology level: the invention scope, territorial rights and protection length, the level of exclusivity conceded to reproduce, modify, make further R\&D or to develop new products based on the invention, the technology development stage, the level of complexity and the skills required to use it, its robustness to operate in different environments, its friendly use, easy and intuitive reproduction and packaging, the number of technologies that must be integrated with the invention to obtain a full commercial product, the possibility of mass production, the compatibility with existing systems, the risks and the costs inherent to future developments, and its social and environmental impact;

- At a market level: the present and emergent competitive technologies, the technology strategic importance, the differentiated applications resulting from the invention and the industries envisaged, the applications market size and growth rate, the emergent and declining costumer segments, the strength of existing firms and brands, the marketing, distribution and sales complexity, the applications life cycle and their revenue streams.

These are some disposition affecting the payments value, but there are other dispositions, such as the rights over 
the improvements made with or on the technology, the possibility of sub-licensing, the payment of patent fees in several countries, the agreement length, and the exclusivity of rights granted, the inclusion of technical services, the provision of equipment or other resources from the part of the university or the firm, the existence of projects and competing R\&D teams, the value of the royalties practiced in the industry and the potential gains from the technology commercialization.

All these dispositions must be considered or appraised so that the nature, the circumstances and the terms of the agreement are reflected in the payment values and in its structure, which can be sub-divided in essentially fourteen categories:

1. Single lump sum payment or paid-up license - a single payment for a determined period of time;

2. Fixed fee per sold unit or technology utilization;

3. Earned royalties, running royalties or pure royalty licenses - royalties based on a percentage of sales or technology utilizations;

4. Up-front payment or up-front fee;

5. Minimum (annual) cash payment - minimums or minimum royalties;

6. Stage payments or milestone payments;

7. Option agreements and options payments;

8. Royalty adjustments;

9. Deferred royalty calculations;

10. Late payment penalties;

11. Termination fees or kill fees;

12. Sub-licensing payments;

13. Equity payments;

14. Support payments;

15. Patent costs reimbursement and maintenance.

An agreement may include multiple types of payments and the above categories are not exhaustive. In the subsequent sections we address each payment type separately.

\subsection{Single lump sum payment or paid-up license}

Licensing agreement including a single lump sum payment for a fixed-term exploitation right are typical of agreements in which the technology offers a relatively low industrial and commercial risk (Johnson, 2007) and they provide advantages for both parties. The TTUs administrative control and communication costs are reduced or eliminated and the firm is not forced to expose sensitive information, and it provides to the licensor, in a single moment, a significant amount of financial resources. To determine the payment amount, it is advisable to make a discounted cash-flow projection, to estimate the profitability of a single payment compared to a series of deferred smaller annual payments (Pressman, 2009), and to establish the payment amount taking into account the invention return on investment.

The test results for the single lump sum payment using the One-sample $T$-test for a Test value $=3$ presents $a$ $p=0.007$ with a $t=-3.74$ meaning that there is evidence to reject the null hypothesis. The single lump sum payment or paid-up license is hardly ever included on technology transfer agreements by the TTUs who participated in this study, being its average frequency of use of 2.00 with a standard deviation of 0.76 .

\subsection{Fixed fee payment}

A fixed payment per sold unit or technology utilization may be established. This value must be updated every year by reference to inflation rates (Johnson, 2001; Poddar \& Sinha, 2002).

The test results for the fixed fee payment using the Onesample $T$-test for a Test value $=3$ presents a $p=0.836$ with a $t=-0.22$ meaning that there is no evidence to reject the null hypothesis. The establishment of a fixed fee payment on technology transfer agreements is a relatively frequent practice by the TTUs, being its average frequency of use of 2.88 with a standard deviation of 1.64 .

\subsection{Earned royalties or running royalties}

Running royalties are based on a percentage of the price of the licensed product, or on a percentage of the product sales operational results. This type of payment shares the risk between the licensor and the licensee, since the licensor receives a larger or a smaller payment depending on the sales success (Heiden \& Petit, 2017; Nabulsi \& Belt, 2015; Planting, Yuskavage, Okubo, Moylan, \& Bond, 2017; Poddar \& Sinha, 2002; Stevens, 2016). The running-royalties are an important licensor signal of confidence in the invention industrial and commercialization success (Johnson, 2007). The running-royalties are often used when the uncertainty in forecasting the sales volume is very high and when the technology and its applications are still at an earlydevelopment stage and it is believed that the involvement of both parties can positively affect the commercialization success. To establish the royalties percentage to be paid, discounted cash-flows, royalty standards, or the real options or Monte Carlo simulation methods can be used.

The test results for the fixed fee payment using the Onesample $T$-test for a Test value $=3$ presents a $p=0.351$ with a $t=1.00$ meaning that there is evidence to reject the null hypothesis. The earned royalties are frequently included on technology transfer agreements by the TTUs, being its average frequency of use of 3.50 with a standard deviation of 1.41 .

\subsection{Up-front payment or up-front fee}

An up-front payment is a payment required by the licensor whose purpose is to assure the licensee commitment in the invention industrialization and commercial success. Upfront payments are obtained in exchange for a reduction in the royalties percentage (Stevens, 2016; ThalhammenReyero, 2008). One common rule, for this type of payments, is the definition of a payment based on the estimative of the value to be obtained in a year where the project is already well under way (Razgaitis, 2003). It is thus necessary to recur to discounted cash-flow projections, but the value of the upfont payment may also reflect the adequate amount that each party deems to be required to keep the project on track towards its commercial success. 
The test results for the Up-front payment or up-front fee using the One-sample $T$-test for a Test value $=3$ presents $a$ $p=0.003$ with a $t=-4.58$ meaning that there is evidence to reject the null hypothesis. The Up-front payment or up-front fee is hardly ever included on technology transfer agreements by the TTUs who participated in this study, being its average frequency of use of 2.25 with a standard deviation of 0.46 .

\subsection{Minimums or minimum cash payment or minimum royalties or annual fee}

Minimum cash payments are annual payments required by the licensor for the licensee to maintain its exploitation rights. The aim is also to assure that due diligence is being taken by the licensee in the invention commercialization success (Kim \& Blacklock, 2009; Stevens, 2016). Its value can be established based on a conservative or optimistic scenario resulting from the sales estimative and it can correspond to one quarter or two quarters of the projected royalties for a certain year (Razgaitis, 2007).

The test results for the minimums using the One-sample $T$-test for a Test value $=3$ presents a $p=0.785$ with a $t=0.28$ meaning that there is no evidence to reject the null hypothesis. The minimums are frequently included on technology transfer agreements by the TTUs, being its average frequency of use of 3.13 with a standard deviation of 1.25 .

\subsection{Stage payments or milestone payments}

These are payments required to the licensee each time certain development or commercialization objectives or milestones are successfully attained (Leone \& Oriani, 2007; Stevens, 2016; UMIP, 2005; Wood, 2004), such as, the conclusion of an R\&D stage, the beginning of sales or the development of a new application based on the technology.

The test results for the milestone payments using the One-sample $T$-test for a Test value $=3$ presents a $p=0.275$ with a $t=-1.18$ meaning that there is no evidence to reject the null hypothesis. Although the null hypothesis has not been rejected the establishment of milestone payments are not frequent among all the TTUs, the average frequency of use is 2.50 with a standard deviation of 1.20 .

\subsection{Option agreements and options payments}

An option is the right to make future decisions relative to the acquisition or exploitation of a technology. Options can be very useful for the development and validation of the technology and its market, and the investors are able to make an informed decision about the acquisition of rights. If an investor wants to conduct additional research and development, the option may include an exclusive right, and in this case, an initial payment is defined. This payment compensates the licensor for deferring its search for licensees during the time the option takes place. Options that imply exclusive rights may condition other opportunities, and in the case the option is not activated, it may affect future deals. Thus, in the option agreement, its duration must be clearly defined, as well as the obligations of each party and the consequences in case the option is not taken (Thalhammen-Reyero, 2008). Option agreements generally last for 6-12 months and they are very useful on the creation of new enterprises (Leone \& Oriani, 2007). Other options are possible, such as the option to obtain a non-exclusive license after an experimentation and testing period.

The test results for the option payments using the Onesample $T$-test for a Test value $=3$ presents a $p=0.142$ with a $t=-1.66$ meaning that there is no evidence to reject the null hypothesis. Although the null hypothesis has not been rejected the establishment of option payments are not frequent among all the TTUs, the average frequency of use is 2.25 with a relevant standard deviation of 1.28 .

\subsection{Royalty adjustments}

An agreement may include the possibility of readjusting the royalties' value. A scale of reductions in the royalties percentage may be introduced to reflect some circumstances, like the reduction of the invention value due to new competing technologies, production and commercialization costs higher than expected, due to the impossibility of obtaining the rights in a certain region or due to the change of an exclusive license into a non-exclusive one (UMIP, 2005). The reduction of royalties may also serve as an incentive to increase the production and its sales. The definition of a lower royalties value, that increases if certain commercial objectives are met, are usually called, kicker royalties (WIPO/ITC, 2005), this increment scale on the royalties values may also be introduced to reflect the circumstances of a favourable industrial and commercial reality due to greater product absorption or due to low production costs, or other favourable industrial and commercialization events.

The test results for the royalty adjustments using the One-sample $T$-test for a Test value $=3$ presents a $p=0.111$ with a $t=-1.82$ meaning that there is no evidence to reject the null hypothesis. Although the null hypothesis has not been rejected the establishment of royalty adjustments are not frequent among all the TTUs, the average frequency of use is 2.13 with a relevant standard deviation of 1.36 .

\subsection{Deferred royalties calculation}

When there is high uncertainty over the technology development results and commercial success and there is a reasonable amount of trust between the parties, it may make sense to define the royalties and other forms of payment after the technology and the market validation has occurred. When payments are set a posteriori, it is important to define deadlines to achieve certain results or to communicate certain objectives, so that the results can be analyzed and the payments defined according to those results. This payment type is mostly used among university spin-off firms where a relation of trust has been built and is present.

The test results for the deferred royalty calculations using the One-sample $T$-test for a Test value $=3$ presents a $p=0.142$ with a $t=-1.66$ meaning that there is no evidence to reject the null hypothesis. Although the null hypothesis has not been rejected the establishment of deferred royalty calculations are not frequent among all the TTUs, the 
average frequency of use is 2.25 with a relevant standard deviation of 1.28 .

\subsection{Late payment penalties}

The date for each payment must be well defined in the agreement and penalties must be established in case of default, to discourage future defaults (Razgaitis, 2003).

The test results for the late payment penalties using the One-sample $T$-test for a Test value $=3$ presents a $p=0.068$ with a $t=-2.16$ meaning that there is no evidence to reject the null hypothesis. Although the null hypothesis has not been rejected the establishment of deferred royalty calculations are not frequent among all the TTUs, the average frequency of use is 2.00 with a relevant standard deviation of 1.31 .

\subsection{Termination fees or kill fees}

A license presupposes a fixed duration. If a contract is broken, fees must be paid to the institution, to compensate for lost opportunities. This type of payment is usually used as a measure of licensees' credibility (Berneman, Davis, O’Reilley, \& Raymond, 2014; Razgaitis, 2007).

The test results for the termination fees using the Onesample $T$-test for a Test value $=3$ presents a $p=0.051$ with a $t=-2.35$ meaning that there is no evidence to reject the null hypothesis. Although the null hypothesis has not been rejected the establishment of termination fees are not frequent among all the TTUs, the average frequency of use is 1.88 with a relevant standard deviation of 1.36 .

\subsection{Sub-licensing payments}

Sometimes the licensee has access to large networks and is interested in distributing the technology to third parties, which enhances its sales and liquidity. These contracts must preview how the gains will be distributed among licensors, licensees and sub-licensees. Sub-licensing is common in exclusive licensing agreements (Berneman et al., 2014; Franko \& Ionescu-Pioggia, 2006; Stevens, 2016).

The test results for the sub-licensing payments using the One-sample $T$-test for a Test value $=3$ presents a $p=0.316$ with a $t=1.08$ meaning that there is no evidence to reject the null hypothesis. The sub-licensing payments are frequently included on technology transfer agreements by the TTUs, being its average frequency of use of 3.50 with a standard deviation of 1.31 .

\subsection{Equity payments}

The university may opt for an equity participation in a firm, assuring financial support for the firm or technology transfer without or at reduced cost for the firm. The most successful universities in terms of technology transfer usually have some form of equity in spin-off firms and have explicit and proactive measures directed towards its development (Lockett, Wright, \& Franklin, 2003). The financial return via equity participation is generally higher than the one obtained via licensing, and universities seem to be more engaged in equity if they are more experienced in technology transfer (Bray \& Lee, 2000; Feldman, Feller, Bercovitz, \& Burton, 2002).

The test results for the equity payments using the Onesample $T$-test for a Test value $=3$ presents a $p=0.001$ with a $t=-5.61$ meaning that there is evidence to reject the null hypothesis. The equity payments are hardly ever included on technology transfer agreements by the TTUs who participated in this study, being its average frequency of use of 1.50 with a standard deviation of 0.76 .

\subsection{Support payments}

The licensor support in terms of technical assistance is particularly important for sophisticated technologies and during the license early years where the licensee goes through a learning curve process, and they can have a positive impact in terms of investment risk reduction, and for the licensor they are an important source of revenues and they enhance the relationship with the licensee and the possibility of establishing new commercial and investment relations (Rocha, 2009).

The test results for the support payments using the Onesample $T$-test for a Test value $=3$ presents a $p=0.180$ with a $t=-1.49$ meaning that there is no evidence to reject the null hypothesis. Although the null hypothesis has not been rejected the establishment of support payments are not frequent among all the TTUs, the average frequency of use is 2.38 with a relevant standard deviation of 1.19 .

\subsection{Patent costs reimbursement and maintenance}

Payments for the costs incurred with patent applications and maintenance fees. This payments are usually asked when an exclusive right is granted, as long as this costs do not exceed the market value of the asset being licensed (Rocha et al., 2013; Stevens, 2016).

The test results for the patent costs reimbursement and maintenance using the One-sample $T$-test for a Test value $=3$ presents a $p=0.785$ with a $t=0.28$ meaning that there is no evidence to reject the null hypothesis. The patent costs reimbursement and maintenance are frequently included on technology transfer agreements by the TTUs, being its average frequency of use of 3.13 with a standard deviation of 1.25 .

\subsection{Types of payment used by the TTUs in licensing agreements}

A licensing agreement creates contractual obligations between the licensor and the licensee, and several types of payment, that reflect several considerations whose nature may be economical, technological, legal or commercial, may be included on the contract. The most frequent types of payment in use by the TTUs are the running royalties, but other payments are also frequently included on technology transfer agreements, such as the minimum cash payments or the milestone payments, but there is usually a concern in assessing the firms position and there is also a concern 
Table 1 Earnings distribution within Portuguese public universities. This information does not exempt consulting the intellectual property rights regulation of each university.

\begin{tabular}{|c|c|}
\hline University & Earnings distribution \\
\hline \multirow{2}{*}{$\begin{array}{l}\text { University of Aveiro } \\
\text { (Universidade de Aveiro) }\end{array}$} & $40 \%$ for the inventors \\
\hline & $60 \%$ for the University (negotiable) \\
\hline \multirow{5}{*}{$\begin{array}{l}\text { University of Beira Interior } \\
\text { (Universidade da Beira } \\
\text { Interior) }\end{array}$} & $50 \%$ for the inventors \\
\hline & $15 \%$ for the inventor Faculty \\
\hline & $35 \%$ for the University, from which \\
\hline & $20 \%$ for the Rectory \\
\hline & $15 \%$ for the coordinating research Institute \\
\hline \multirow{4}{*}{$\begin{array}{l}\text { University of Coimbra } \\
\text { (Universidade de } \\
\text { Coimbra) }\end{array}$} & $55 \%$ for the inventors \\
\hline & $45 \%$ for the University, among which: \\
\hline & $30 \%$ for the Faculty \\
\hline & $15 \%$ for the Rectory \\
\hline \multirow{4}{*}{$\begin{array}{l}\text { University of Minho } \\
\text { (Universidade do Minho) }\end{array}$} & $50 \%$ for inventors \\
\hline & $50 \%$ for the University, from which \\
\hline & $\begin{array}{l}15 \% \text { for the research centre, or in justified occasions for the organic unit or department where } \\
\text { the invention was originated }\end{array}$ \\
\hline & $\begin{array}{l}35 \% \text { for the Rectory, value that will also support the remuneration of entities on which the } \\
\text { university has delegated executive competencies. }\end{array}$ \\
\hline \multirow{2}{*}{$\begin{array}{l}\text { New University of Lisbon } \\
\text { (Universidade Nova de } \\
\text { Lisboa) }\end{array}$} & $30-55 \%$ for inventors, depending on the process profitability \\
\hline & $\begin{array}{l}\text { Remaining for the University (Rectory), to be distributed among agreements to be established, } \\
\text { on a case by case basis, with the involved organic units }\end{array}$ \\
\hline \multirow{8}{*}{$\begin{array}{l}\text { University of Lisbon } \\
\quad \text { (Universidade de Lisboa) }\end{array}$} & $P<=5000 €$ \\
\hline & $100 \%$ for the inventors \\
\hline & $5000 €<P<=100,000 €$ \\
\hline & $75 \%$ for the inventors \\
\hline & $25 \%$ for the university \\
\hline & $P>100,000 €$ \\
\hline & $25 \%$ for the researchers \\
\hline & $75 \%$ for the university \\
\hline \multirow{2}{*}{$\begin{array}{l}\text { University of Porto } \\
\text { (Universidade do Porto) }\end{array}$} & $60 \%$ for inventors \\
\hline & $\begin{array}{l}30 \% \text { for the inventor organic unit or other unit of the University of Porto } \\
10 \% \text { for the University of Porto }\end{array}$ \\
\hline \multirow{2}{*}{$\begin{array}{l}\text { University of Trás-os-Montes } \\
\text { and Alto Douro }\end{array}$} & $50 \%$ for the inventors \\
\hline & $50 \%$ for the university \\
\hline \multirow{4}{*}{$\begin{array}{l}\text { Technical University of } \\
\text { Lisbon } \\
\text { (Universidade Técnica de } \\
\text { Lisboa) }\end{array}$} & $80 \%$ for inventors \\
\hline & $20 \%$ spited in equal parts: \\
\hline & Half for the inventor R\&D unit \\
\hline & Remaining for technology transfer activities \\
\hline University of Évora & $\begin{array}{l}\text { The profits from the technology transfer agreement will be distributed according to a written } \\
\text { contract between the University and the inventor or creator, in the absense of a written } \\
\text { contract the profits are evenly distributed. The profits retained by the University will be } \\
\text { distributed accordingly to a rectory decision. }\end{array}$ \\
\hline \multirow[t]{4}{*}{ University of Algarve } & $50 \%$ for the inventor \\
\hline & $50 \%$ for the university \\
\hline & $25 \%$ for the Rectory \\
\hline & $25 \%$ for the inventor School or Faculty \\
\hline
\end{tabular}

on establishing a mutual relationship, especially when the firms have previous relations with the university or when a new firm is established to exploit an invention. This concern is also reflected on the frequency of payments established after a period of experimentation and tests (deferred royalty calculation) - some TTUs express apprehension on establishing this type of payments because of potential conflicts that a posteriori payment agreements may generate.
In what concerns to support payments for scientific and technical services they are relatively frequent on the TTUs licensing agreements. These services, a mixture of maintenance and technical assistance, increases the licensor revenues, and they also have the advantage of keeping the relationship with the licensee enhancing the possibility of transferring other solutions. The grant of sublicensing rights is also common, in what concerns to payments from equity 
participation their not common. Among the types of payments least in use by the TTUs are the single lump sum payments, termination fees and the late payments penalties.

\section{Earnings distribution}

Each university has its own rules or set of principles that define how the gains from licensing agreements are distributed within the university stakeholders. Higher fees paid to the inventors seem to be positively related to the number of inventions, to the financial return of the licenses and in the attraction of abler researchers (Lach \& Schankerman, 2003), and universities tend to pay larger percentages to inventors that take the initiative to create their own spin-off firm, these higher fees are aimed to compensate the inventors initiative and risk taking attitude (CEC, 2007; Lockett et al., 2003). In what concerns to the TTUs, they typically receive $10-25 \%$ of the license revenues and the university tends to subsidize directly the TTU activities during several years, until it becomes self-sufficient (CEC, 2007). Many years can pass before self-sufficiency is attained, and the TTU must reach a balance between the resources available and what they can protect. As a rule of thumb, only one in ten invention disclosures' is patentable, and only one in ten patents is licensable (Dodds \& Somersalo, 2007). Evaluation practices are thus essential in the process of decision making regarding patents and in the marketing and licensing of inventions.

The distribution of licensing agreements revenues among the inventors within the universities at study range from $30 \%$ to $60 \%$ and, these universities, do not specify the earnings distribution among their TTU and when a new spin-off firm is created by university personnel. The remaining earnings are used to support the research centre where the invention took place, to acquire equipment and materials and to make further research work on the technology having in mind future gains. Revenues are also used in transversal activities, mainly in the management and reinforcement of intellectual property rights and in the development of strategic R\&D projects.

Details on the earnings distribution within Portuguese universities can be consulted in Table 1. This information has been obtained by reviewing the intellectual property rights regulation of each Portuguese university. These documents have been obtained by asking the TTUs a copy or by consulting the document on the universities or TTUs website.

\section{Conclusion}

From the empirical results obtained several conclusions could be reached. The following is a summary of some important ones, regarding the payment types and the earning distribution.

Payment types:

a) The more frequent types of payment are the running royalties, but other payment types are frequently included in the technology transfer agreements, such as the minimums, the milestone payments, and the patent costs reimbursement and maintenance; b) Payment for scientific and technical support services increase the licensor revenues and they have the advantage of keeping the relationship with the licensee enhancing the possibility of transferring other solutions;

c) Deferred payment calculations are in use especially when the firm has previous relations with the university or when a new spin-off firm is established to exploit an invention. Some TTUs express apprehension on establishing this type of payments because of potential conflicts which can be generated;

d) With regard to the investment on new spin-off firms social capital we have noticed a lack of University technology transfer units on this engagement process, which does not mean a lack of participation by other university units that may be happening. We should remember that according to our literature review the participation on spin-off firms usually has a higher investment return than the one usually obtained with a licensing agreement (Bray \& Lee, 2000; Feldman et al., 2002).

Earnings distribution:

e) Revenues from licensing agreements are mainly used to reward the researcher or research team who produced the invention and to support their unit of affiliation;

f) Allocation of revenues to the inventors differs from university to university and has a range from $30 \%$ to $80 \%$ of the total revenues;

g) University intellectual property rights regulations, usually do not specify the allocation of revenues for the TTUs, nor do they specify a different distribution of revenues when a new spin-off firm is created. Although we should notice that according to our literature review universities tend to pay larger percentages to inventors who take the initiative to create their own spin-off firm as a means to compensate their initiative and risk taking attitude (Lach \& Schankerman, 2003; Lockett et al., 2003).

\section{Acknowledgements}

This work was partially funded by COMPETE-POCI-01-0145FEDER-007043 and FCT-UID-CEC-00319-2013.

\section{References}

Berneman, L., Davis, T., O’Reilley, P., \& Raymond, M. (2014). Maximizing the value of license agreements. Les Nouvelles. http:// www.texelerate.net/articles/Maximizing_Value_Licenses_\%20 les_Nouvelles_March\%20_2014.pdf

Bray, M., \& Lee, J. (2000). University revenues from technology transfer: Licensing fees versus equity positions. Journal of Business Venturing, 15(5-6), 385-392.

CEC. (2007). Improving knowledge transfer between research institutions and industry across Europe: Embracing open innovation. Voluntary guidelines for universities and other research institutions to improve their links with industry across Europe. Communication from the Commission of European Communities COM (2007) 182 Final, SEC (2007) 449.

CWUR. (2015). Center for World University Rankings.. http: / / cwur. org/2015/portugal.php

Dodds, J., \& Somersalo, S. (2007). Practical considerations for the establishment of a technology transfer office. In A. Krattiger, 
R. T. Mahoney, L. Nelsen, ..., \& S. Kowalski (Eds.), Intellectual property management in health and agricultural innovation: $A$ handbook of best practices (pp. 575-579). MIHR/PIPRA: Oxford, UK/Davis, CA.

Feldman, M., Feller, I., Bercovitz, J., \& Burton, R. (2002). Equity and the technology transfer strategies of American Research Universities. Management Science, 48(1), 105-121.

Franko, M., \& lonescu-Pioggia, M. (2006). Making the right moves. A practical guide to scientific management for postdocs and new faculty (2nd ed.). Research Triangle Park, NC/Chevy Chase, MD: Burroughs Wellcome Fund/Howard Hughes Medical Institute.

Heiden, V., \& Petit, N. (2017). Patent trespass and the royalty gap: Exploring the nature and impact of "patent holdout". Hoover Institution Working Group on Intellectual Property, Innovation, and Prosperity Stanford University. https://hooverip2. org/wp-content/uploads/ip2-17010-paper.pdf

Johnson, H. (2001). Establishing royalty rates in licensing agreements. CMA Management, 75(1), 16.

Johnson, P. (2007). Reasonable royalty damages and license structure. Econ One Newsletter.

Kim, S., \& Blacklock, P. (2009). Patent licensing basics. South Florida Legal Guide.

Lach, S., \& Schankerman, M. (2003). Incentives and invention in universities (NBER Working Paper $n^{\circ}$ 9727). National Bureau of Economic Research.

Leone, M. \& Oriani, R. (2007). The option value of patent licenses. University of Bologna, Luiss Guido Carli University.

Lockett, A., Wright, M., \& Franklin, S. (2003). Technology transfer and universities spin-out strategies. Small Business Economics, 20(2), 185-200.

Nabulsi, B., \& Belt, E. (2015). The patent is dead; long live the royalties!. IN VIVO The Business \& Medicine Report. http://www. mccarter.com/files/Uploads/Documents/Website/InVIVO PatentlsDead1505.pdf

Planting, M., Yuskavage, R., Okubo, S., Moylan, C., \& Bond, J. (2017). The economic contribution of university/nonprofit inventions in the United States. Prepared for the Biotechnology Innovation Organization and the Association of University Technology Managers by Lori Pressman, AUTM. https://www. autm.net/AUTMMain/media/Partner-Events/Documents/ Economic-_Contribution_University-Nonprofit_Inventions_US 1996-2015_BIO_AUTM.pdf
Poddar, S., \& Sinha, U. (2002). The role of fixed fee and royalty in patent licensing (Working Paper $n^{\circ}$ 0211). National University of Singapore \& Indian Statistical Institute.

Pressman, D. (2009). Patent it yourself: Your step-by-step guide to filing at the U.S. patent office (14th ed.). Berkeley, CA: NOLO.

Razgaitis, R. (2003). Valuation and pricing of technology-based intellectual property. Hoboken, NJ: John Wiley \& Sons.

Razgaitis, R. (2007). Pricing the intellectual property of early-stage technologies: A primer of basic valuation tools and considerations. In A. Krattiger, R. T. Mahoney, L. Nelsen, .... \& S. Kowalski (Eds.), Intellectual property management in health and agricultural innovation: A handbook of best practices (pp. 813-860). MIHR/PIPRA: Oxford, UK/Davis, CA.

Rocha, A. (2009). Avaliação e licenciamento de tecnologia em universidades (master's thesis). Braga, Portugal: Universidade do Minho.

Rocha, A., Águia, C., Chaves, D., Pinho, E., Queirós, H., Aguiar, J., ..., \& Vilela, T. (2013). Manual para a proteção, gestão e valorização da propriedade intelectual. Porto, Portugal/Lisboa, Portugal: COTEC Portugal/INPI.

Stevens, A. (2016). Intellectual property valuation manual for academic institutions. Committee on development and intellectual property (CDIP). WIPO - World Intellectual Property Organization. http://www.wipo.int/edocs/mdocs/mdocs/ en/cdip_17/cdip_17_inf_4.pdf

Thalhammen-Reyero. (2008). Transfer and valuation of biomedical intellectual property. In J. L. Horvath, \& D. W. Chodikoff (Eds.), Taxation and valuation of technology: Theory, practice and the law. New South Wales, Australia: The Federation Press (chapter 22).

UMIP. (2005). Licensing: A researcher's guide. Manchester, UK: The University of Manchester Intellectual Property Limited and Eversheds LLP.

WIPO/ITC. (2005). Exchanging value: Negotiating technology licensing agreements. A training manual. Geneva, Switzerland: WIPO.

Wood, T. (2004). Launching patent licensing for an emerging company. Paper presented at the Sixth Annual Seminar on Licensing Intellectual Property, University of Dayton School of Law, Ohio, USA.

Wright, M. (2014). Academic entrepreneurship, technology transfer and society: Where next? The Journal of Technology Transfer, 39(3), 322-334. 